\title{
Novel hemizygous nonsense mutation in DRP2 is associated with inherited neuropathy
}

Ricardo H. Roda, MD, PhD, Brett A. McCray, MD, PhD, Christopher J. Klein, MD, and Ahmet Hoke, MD, PhD

Neurol Genet 2018;4:e220. doi:10.1212/NXG.0000000000000220
Correspondence
Dr. Roda:

rroda1@jhmi.edu

Mutations in DRP2 (OMIM \#300052) encoding dystrophin-related protein 2, a 957 amino acid protein, were identified in a single patient with X-linked Charcot-Marie-Tooth (CMT) disease and are associated with familial autism. ${ }^{1,2}$ DRP2 is predominantly expressed in the brain and spinal cord and functionally interacts with periaxin ( $P R X$, OMIM \#605725), a known causative CMT gene (OMIM \#614895 and \#145900), in the PRX-DRP2-dystroglycan (PDG) complex. ${ }^{3}$ The PDG complex supports and maintains Cajal bands, which are cytoplasmic extensions that run along the length of myelinated axons and are required for establishing a proper internodal length. $^{4-6}$

A nonsense $D R P 2$ c.805C $>\mathrm{T}$ (Q269X) mutation was found in a patient with sensorimotor neuropathy, with intermediate conduction velocities and absence of Cajal bands within dermal nerves. ${ }^{1}$ Here, we report another patient with a novel nonsense mutation in DRP2 with sensorimotor polyneuropathy and histologic myelin abnormalities. This report extends the known mutation spectrum of DRP2 and provides further evidence of its association with inherited neuropathy.

\section{Case report}

The index patient is a 42-year-old man who developed fatigue, numbness and tingling in his fingers and toes, and headaches at the age of 18 . Over time, he developed patchy burning in his extremities, intermittent numbness in his face, heat intolerance, and excessive sweating. There was no family history of neuropathy. Nerve conduction studies at the age of 33 demonstrated mildly slowed conduction velocities and prolonged F-wave latencies in the lower extremities. A left sural nerve biopsy showed fibers with tomaculae, thinly myelinated fibers, and a small focus of perivascular epineurial inflammation. A lumbar puncture was performed and showed normal CSF protein levels and cell counts. Testing for diabetes mellitus, Sjogren syndrome, HIV, and Lyme disease was negative, and hexosaminidase $\mathrm{A}$ and $\alpha$-galactosidase levels were normal. Testing for mutations of PMP22, MFN2, and GBJ1 was negative.

At the age of 40, examination showed normal cognition, cranial nerves, muscle bulk, tone, and strength. He was able to walk on his heels and toes. Deep tendon reflexes were mildly reduced at the ankles $(1+)$ but were otherwise normal. There was multimodal distal sensory loss with light touch, pinprick, and temperature reduced in the lower extremities to the mid-shins and in the upper extremities to the mid-forearms. Joint position sense was preserved, and vibration sense was normal except for a mild reduction at the left first toe. Augmented Romberg (feet in tandem position) was positive. Repeat electrophysiology revealed evidence of lower extremity demyelinating neuropathy with nonuniformly reduced conduction velocities of the bilateral peroneal motor nerves (right $31 \mathrm{~m} / \mathrm{s}$, left $22 \mathrm{~m} / \mathrm{s}$, normal $\geq 40 \mathrm{~m} / \mathrm{s}$ ) with normal distal latencies, partial motor conduction block in the bilateral peroneal motor nerves recorded at the extensor

From the Department of Neurology (R.H.R., B.A.M., A.H.), Johns Hopkins University School of Medicine, Baltimore, MD; and Department of Neurology (C.J.K.), Mayo Clinic, Rochester, MN.

Funding information and disclosures are provided at the end of the article. Full disclosure form information provided by the authors is available with the full text of this article at Neurology.org/NG.

The Article Processing Charge was funded by the authors.

This is an open access article distributed under the terms of the Creative Commons Attribution-NonCommercial-NoDerivatives License 4.0 (CC BY-NC-ND), which permits downloading and sharing the work provided it is properly cited. The work cannot be changed in any way or used commercially without permission from the journal. 
digitorum brevis muscle ([ankle vs fibular head stimulation]: right [2.5 vs $0.9 \mathrm{mV}$ ], left [1.5 vs $0.1 \mathrm{mV}]$ ), and markedly prolonged lower extremity F-wave latencies (right tibial 82 milliseconds, left peroneal 73 milliseconds, normal $<56$ milliseconds). Upper extremity testing showed a normal conduction velocity in the median motor nerve and a slightly reduced velocity $(46 \mathrm{~m} / \mathrm{s}$, normal $\geq 50 \mathrm{~m} / \mathrm{s})$ in the ulnar motor nerve. Skin biopsy and autonomic testing were normal.

Electron microscopy of his sural nerve revealed a mild reduction in the density of large myelinated and unmyelinated axons as well as prominent variability in myelin thickness with many thinly myelinated fibers and some abnormally thick myelinated fibers (figure). We observed many fibers with delamination of myelin, occasional Cajal bands, rare tomaculae, rare active demyelination, and rare miniature onion bulbs indicative of prior demyelination and attempted remyelination. Whole-exome sequencing revealed a hemizygous c.1039C $>\mathrm{T}$, p.Q347X variant in DRP2 that creates a premature stop codon. This variant is not present in the database of the Exome Aggregation Consortium (exac. broadinstitute.org, September 2016). His unaffected mother is a carrier for the change.

\section{Discussion}

In this report, we present a patient with early adult-onset sensorimotor neuropathy with biopsy-proven myelination abnormalities and a likely pathogenic hemizygous mutation in the $\mathrm{X}$-linked gene DRP2. This mutation produces a premature stop codon and is expected to lead to a loss of functional protein and likely a complete absence of DRP2 in men. ${ }^{1,7}$ The biopsy findings are reminiscent of the previously reported
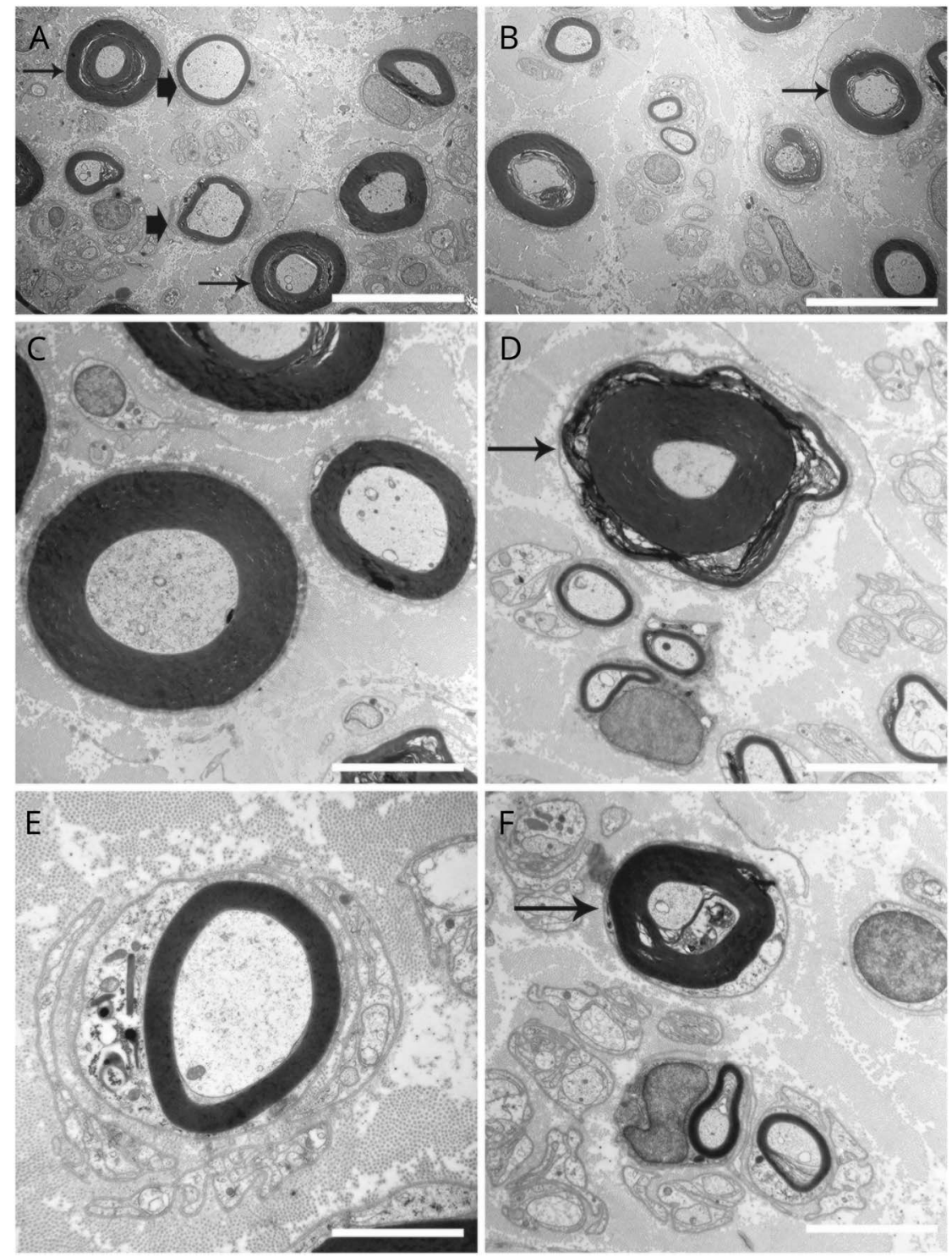

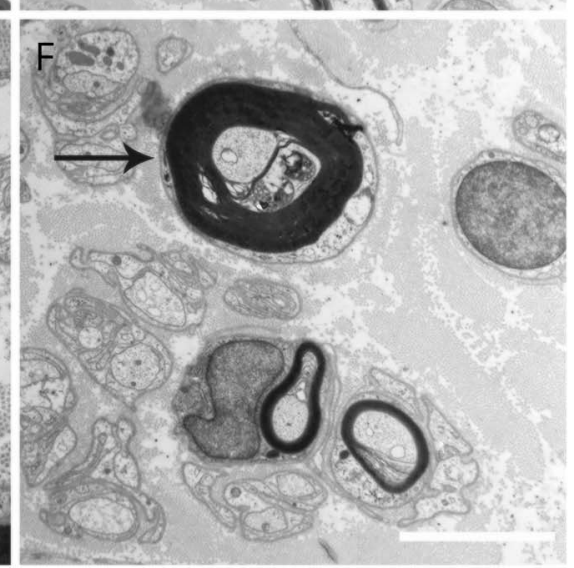

( $A$ and $B$ ) Sural nerve biopsy shows variability in myelin thickness, with some fibers exhibiting thicker myelin sheets relative to axon diameter (thin arrows) and many others harboring thin myelin (thick arrowheads). Many of the thicker myelinated fibers showed delamination. (C and D) Higher power view of myelin thickness variability. Thickly myelinated axon (thin arrow) shows a small tomacula. (E) Miniature onion bulb formation. (F) A myelinated axon (thin arrow) undergoing demyelination. Scale bars denote $10 \mu \mathrm{m}$ in $A$ and $B$, $5 \mu \mathrm{m}$ in $\mathrm{C}$ and $\mathrm{D}$, and $2 \mu \mathrm{m}$ in $\mathrm{E}$ and $\mathrm{F}$. 
patient with DRP2 mutation who displayed the absence of Cajal bands in dermal nerves, and to the histologic features of Drp2-null mice, which show disrupted appositions of Cajal bands, focal hypermyelination, demyelination, and tomaculalike formations. ${ }^{1,8}$ Similarly, $\operatorname{Pr} x$-null mice also show the absence of Cajal bands, shortened internodal length, and reduced conduction velocities. ${ }^{9}$ It is important that the patient reported here had features of both developmental dysmyelination as well as nonuniform demyelination, the latter of which was not present in the previously reported patient with DRP2 mutation. This report provides further evidence linking truncating DRP2 mutations with demyelinating neuropathy and suggests that $D R P 2$ variants should be considered when evaluating patients suspected of inherited neuropathy.

\section{Author contributions}

Dr. Roda: drafting and revision of the manuscript and analysis of patient data. Dr. McCray: critical analysis and revision of the manuscript. Dr. Klein: patient care and critical analysis and revision of the manuscript. Dr. Hoke: patient care, electron microscopy, and critical analysis and revision of the manuscript.

\section{Study funding}

No targeted funding reported.

\section{Disclosure}

$\mathrm{R}$. Roda and McCray have received research support from the NIH. B. C. Klein serves on the CMTA Research and Therapeutics board (a nonprofit patient support group); serves on the editorial board of Neurology ${ }^{\circledR}$; and receives research support from a Mayo Clinic research grant. Dr. Hoke serves on the scientific advisory board of the Foundation for Peripheral
Neuropathy; serves on the editorial boards of Experimental Neurology and Annals of Clinical Translational Neurology; holds patents for Use of ethoxyquin to prevent neuropathy and for Electro-spun fiber mesh to help nerve regeneration; is an employee of Johns Hopkins University; has served as a consultant for Neurocrine Inc.; has received research support from the $\mathrm{NIH}$, the Foundation for Peripheral Neuropathy, and the Dr. Miriam and Sheldon G. Adelson Medical Research Foundation; gave expert testimony on GBS for National Vaccine Injury Program, and gave expert testimony on peripheral neuropathy for Arnold \& Porter Kaye Scholer LLP. Full disclosure form information provided by the authors is available with the full text of this article at Neurology.org/NG.

Received August 8, 2017. Accepted in final form December 12, 2017.

\section{References}

1. Brennan KM, Bai Y, Pisciotta C, et al. Absence of dystrophin related protein-2 disrupts Cajal bands in a patient with Charcot-Marie-Tooth disease. Neuromuscul Disord 2015;25:786-793.

2. Toma C, Torrico B, Hervas A, et al. Exome sequencing in multiplex autism families suggests a major role for heterozygous truncating mutations. Mol Psychiatry 2014;19: 784-790.

3. Roberts RG, Freeman TC, Kendall E, et al. Characterization of DRP2, a novel human dystrophin homologue. Nat Genet 1996;13:223-226.

4. Guilbot A, Williams A, Ravise N, et al. A mutation in periaxin is responsible for CMT4F, an autosomal recessive form of Charcot-Marie-Tooth disease. Hum Mol Genet 2001;10:415-421.

5. Court FA, Sherman DL, Pratt T, et al. Restricted growth of Schwann cells lacking Cajal bands slows conduction in myelinated nerves. Nature 2004;431:191-195.

6. Sherman DL, Fabrizi C, Gillespie CS, Brophy PJ. Specific disruption of a schwann cell dystrophin-related protein complex in a demyelinating neuropathy. Neuron 2001;30: 677-687.

7. Inoue $\mathrm{K}$, Khajavi M, Ohyama $\mathrm{T}$, et al. Molecular mechanism for distinct neurological phenotypes conveyed by allelic truncating mutations. Nat Genet 2004;36:361-369.

8. Sherman DL, Wu LM, Grove M, Gillespie CS, Brophy PJ. Drp2 and periaxin form Cajal bands with dystroglycan but have distinct roles in Schwann cell growth. J Neurosci 2012;32:9419-9428.

9. Gillespie CS, Sherman DL, Fleetwood-Walker SM, et al. Peripheral demyelination and neuropathic pain behavior in periaxin-deficient mice. Neuron $2000 ; 26: 523-531$. 


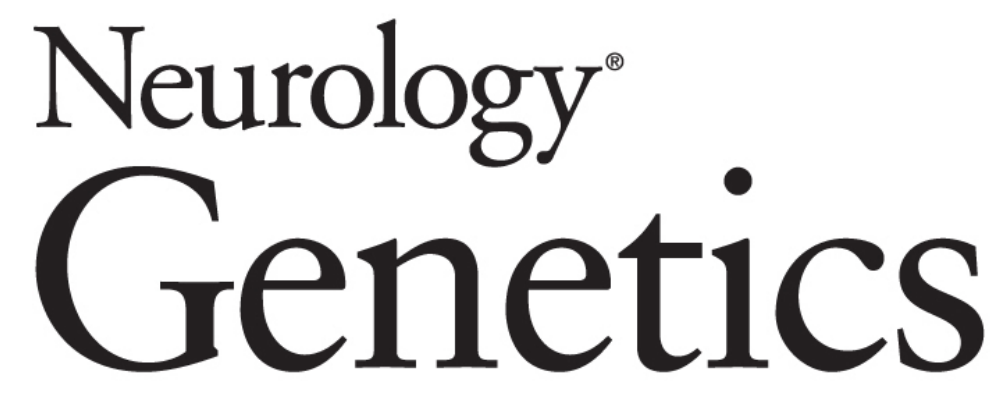

Novel hemizygous nonsense mutation in $D R P 2$ is associated with inherited neuropathy Ricardo H. Roda, Brett A. McCray, Christopher J. Klein, et al. Neurol Genet 2018;4;

DOI 10.1212/NXG.0000000000000220

This information is current as of January 24, 2018

$\begin{array}{ll}\begin{array}{l}\text { Updated Information \& } \\ \text { Services }\end{array} & \begin{array}{l}\text { including high resolution figures, can be found at: } \\ \text { http://ng.neurology.org/content/4/1/e220.full.html }\end{array} \\ \text { References } & \begin{array}{l}\text { This article cites } 9 \text { articles, } 1 \text { of which you can access for } \\ \text { http://ng.neurology.org/content/4/1/e220.full.html\#\#ref-list- }\end{array} \\ \text { Subspecialty Collections } & \begin{array}{l}\text { This article, along with others on similar topics, appears in } \\ \text { following collection(s): } \\ \text { Peripheral neuropathy } \\ \text { http://ng.neurology.org//cgi/collection/peripheral_neurop }\end{array} \\ & \begin{array}{l}\text { Information about reproducing this article in parts (figure } \\ \text { its entirety can be found online at: }\end{array} \\ \text { hermissions \& Licensing } & \begin{array}{l}\text { http:/ng.neurology.org/misc/about.xhtml\#permissions } \\ \text { http://ng.neurology.org/misc/addir.xhtml\#reprintsus }\end{array} \\ \text { Reprints } & \end{array}$

Updated Information \&

References

Subspecialty Collections

Permissions \& Licensing

Reprints
Information about ordering reprints can be found online:

Neurol Genet is an official journal of the American Academy of Neurology. Published since April 2015, it is an open-access, online-only, continuous publication journal. Copyright Copyright ( 2018 The Author(s). Published by Wolters Kluwer Health, Inc. on behalf of the American Academy of Neurology.. All rights reserved. Online ISSN: 2376-7839.

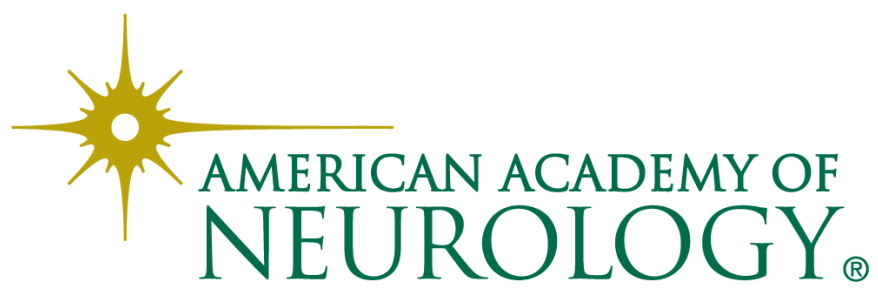

